\title{
Primary pulmonary rhabdomyosarcoma in children: Report of three cases with review of literature
}

\section{Kadabur Nagendrappa Lokesh, Chennagiri S. Premalatal, B. S. Aruna Kumari², L. Appaji²}

Departments of Medical Oncology, ${ }^{1}$ Pathology and ${ }^{2}$ Pediatric Oncology, Kidwai Memorial Institute of Oncology, Bangalore, Karnataka, India

\author{
Address for correspondence: \\ Dr. Kadabur Nagendrappa Lokesh, \\ Department of Medical oncology, \\ Kidwai Memorial Institute of \\ Oncology, Bangalore - 560 029, \\ Karnataka, India. \\ E-mail:knloki@gmail.com
}

\begin{abstract}
A B S T R A C T
Primary pulmonary rhabdomyosarcoma in children is rare. Three children aged three, nine and three years were evaluated for abnormal shadows on radiological examination with pneumothorax in two cases. Resection and histopathological examination revealed embryonal rhabdomyosarcoma in all and cystic malformation in first case. All the three children were treated with surgery and first two received adjuvant chemotherapy. The disease free duration was 160 months, 19 months and seven months respectively. The literature on primary pulmonary rhabdomyosarcoma in children was reviewed.
\end{abstract}

Key words: Embryonal, pneumothorax, pulmonary, rhabdomyosarcoma

\section{INTRODUCTION}

Rhabdomyosarcoma (RMS) occurs predominantly in infants and children. The most common sites are head and neck, genitourinary tract, and extremities. Primary pulmonary RMS is rare. It accounts for only $0.5 \%$ of childhood RMS and $4.4 \%$ of childhood pulmonary neoplasms. ${ }^{[1,2]}$ To the best of our knowledge, only 27 cases have been reported in the English literature. This is a case series of primary pulmonary RMS in three children.

\section{CASE REPORTS}

\section{Case 1}

A male child aged 3 years, presented with recurrent right-sided pneumothorax with intercostal drainage for 1 year. Mass lesion was suspected and on posterolateral thoracotomy, a whitish-yellow multiple gelatinous soft cystic masses were found which were excised completely. The following roentgenogram showed excellent lung expansion. Histopathological review was suggestive of spindle cell sarcoma and immunohistochemistry (IHC) revealed cells

\begin{tabular}{|l|l|}
\hline \multicolumn{3}{|c|}{ Access this article online } \\
\hline Quick Response Code: & Website: \\
\hline & www.ijmpo.org \\
\hline
\end{tabular}

positive for desmin and MyoD 1, suggestive of embryonal RMS. There was no evidence of metastasis and was staged as group II according to Intergroup rhabdomyosarcoma study (IRS) group. Child had received chemotherapy as per the IRS III protocol and was disease free for 160 months.

\section{Case 2}

A female child aged 9 years, presented to hospital elsewhere with fever, cough, and hemoptysis for 2 months and decreased breath sounds in the right infra-axillary area. She was found to have mass lesion in the apical segment of right lower lobe by chest X-ray [Figure 1] and CT scan [Figure 2]. Patient underwent right thoracotomy with segmentectomy of apical segment of right lower lobe. The histopathology revealed lung tissue with a tumor composed of compact spindle cells arranged in fascicles, cells showed moderate pleomorphism with an occasional mitosis. The dissected two mediastinal lymph nodes showed reactive changes. IHC revealed cells positive for desmin, MyoD 1 , and focally positive for S-100, suggestive of embryonal RMS of spindle cell variant. The metastatic workup was negative. The patient received chemotherapy as per the IRS III protocol and was disease free for 19 months.

\section{Case 3}

A female child aged 3 years, presented with history of dyspnea, fever, and cough for 2 months. She was diagnosed to have right-sided pneumothorax which did not improve following insertion of intercostal drainage. Later, CT scan showed mass lesion in right lower lobe with pneumothorax. She underwent exploratory thoracotomy with subtotal 
excision of right lower lobe mass. Histopathology showed spindle cell sarcoma [Figures 3 and 4] and IHC revealed cells positive for desmin [Figure 5], focally for MyoD 1 [Figure 6] and $\mathrm{H}$-caldesmon, suggestive of embryonal RMS of anaplastic type. Metastatic workup was negative. Parents refused adjuvant chemotherapy and child was disease free for 7 months.

\section{DISCUSSION}

Primary pulmonary RMS is a rare disease in children, accounts for only $0.5 \%$ of pediatric RMSs and $4.4 \%$ of all childhood pulmonary neoplasms. ${ }^{[3]}$ In the IRS involving 646 children with a primary pulmonary lesion, only three were from lung and four were pleural lesions. ${ }^{[4,5]}$ When RMS develops in the pre-existing congenital cystic adenomatoid malformation (CCAM), spontaneous pneumothorax is one of the most common clinical presentation. ${ }^{[1]}$

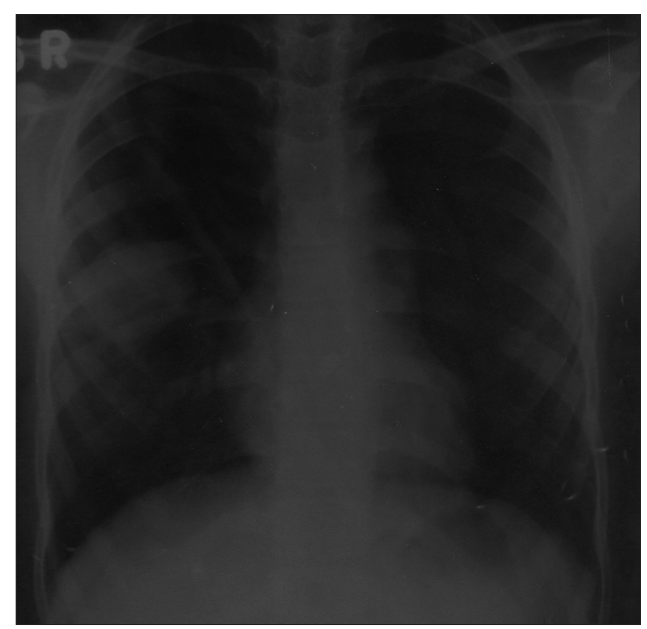

Figure 1: Chest $\mathrm{X}$-ray showing mass lesion in the right mid-zone (Case 2)

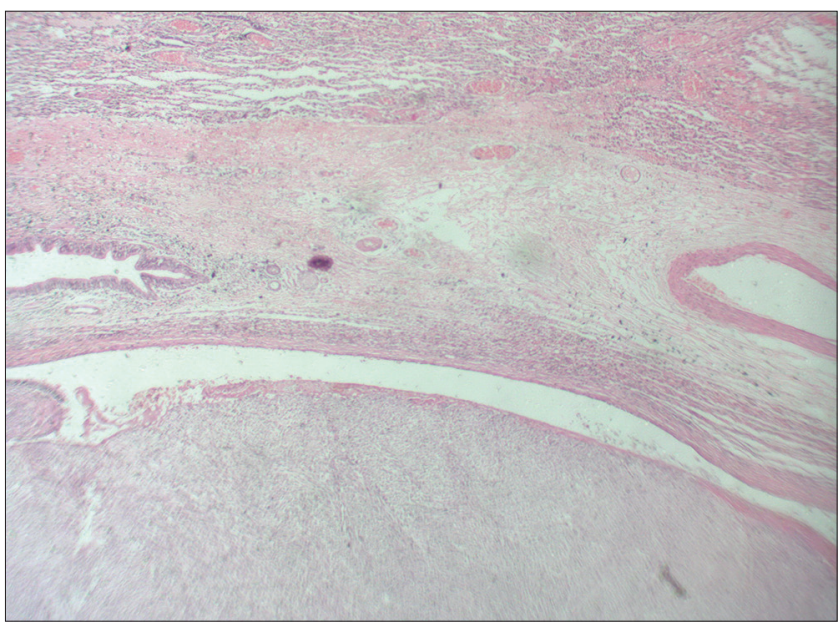

Figure 3: $\mathrm{H}$ and $\mathrm{E}$ (original magnification $\times 100$ ) showing lung alveoli on top, bronchiole and embryonal rhabdomyosarcoma below
In our case series, the cystic malformation was found only in case 1, which was confirmed by the intraoperative findings. As this child had undergone surgery elsewhere, we do not have enough evidence to say it as a CCAM.

Cystic pulmonary malformation can serve as a substrate for the development of primary RMS, pleuropulmonary blastoma, myxosarcoma, reticulosarcoma, hemangiopericytoma, bronchogenic carcinoma, and mesenchymoma. ${ }^{\left[{ }^{[6]}\right.}$

The commonest primary lung tumors under the age of 15 years are bronchial adenoma (carcinoid, mucoepidermoid carcinoma, and adenoid cystic carcinoma), bronchogenic carcinoma (mostly as adenocarcinoma or undifferentiated small cell carcinoma), and plasma cell granuloma. In contrast, leiomyosarcoma, fibrosarcoma, bronchial papillomatosis, pulmonary RMS, and pulmonary blastoma are rare. ${ }^{[1]}$

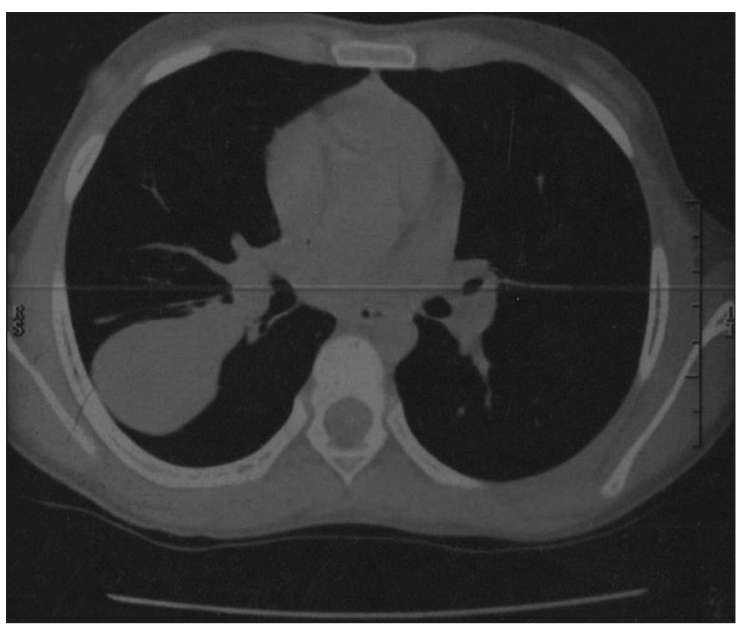

Figure 2: CT scan chest showing mass lesion in the apical segment of right lower lobe (Case 2)

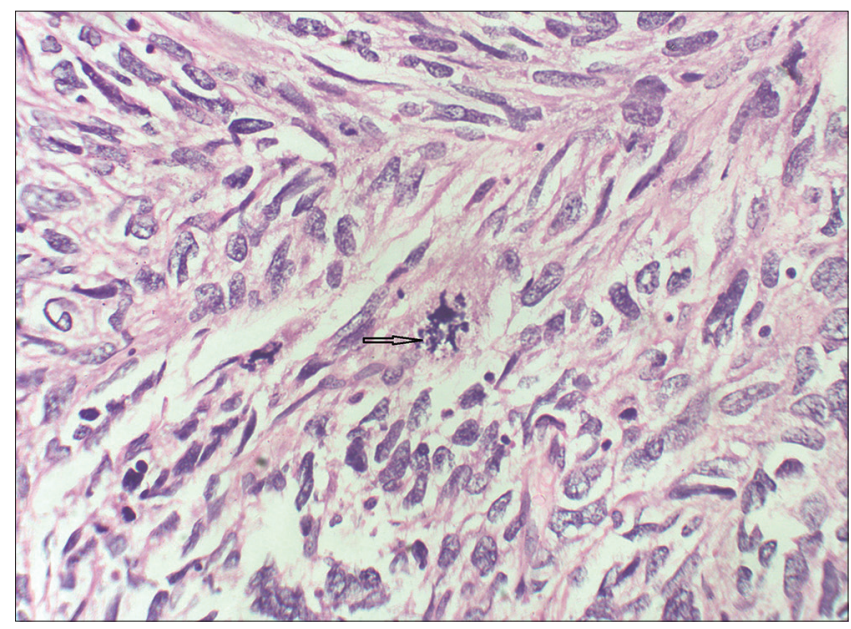

Figure 4: $\mathrm{H}$ and $\mathrm{E}$ (original magnification $\times 400$ ) showing spindle-shaped cells, with a mitotic figure in the center. Few strap cells with bright eosinophilic cytoplasm (arrow) 


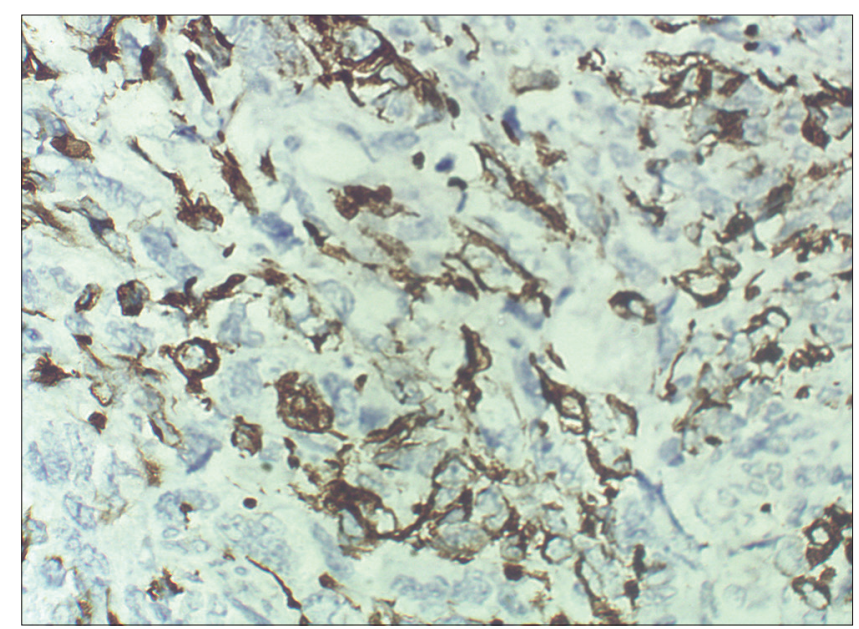

Figure 5: Immunohistochemical (ABC technique, $\times 400)$ examination shows cytoplasmic positivity for desmin in the spindle cells

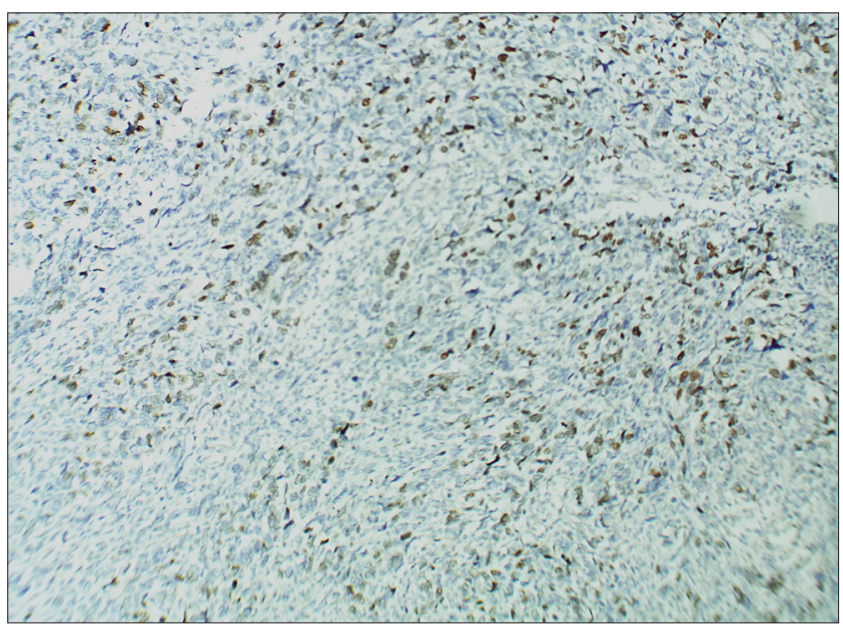

Figure 6: Immunohistochemical $(A B C$ technique, $\times 100)$ examination shows positivity for MyoD 1 in the nuclei of spindle cells

On reviewing the literature, the first case of pulmonary RMS was published by McDonald and Heather in 1939. [7] Among the 30 cases (including our cases) [Table 1], 16 arose from pre-existing pulmonary cystic lesions and 14 without any malformation including two from the bronchial wall. ${ }^{[8,23]}$ The median age was 53 (range 13-168) months. The distribution was equal in both the lungs. Among the 30 cases, 29 underwent surgery, 18 received adjuvant chemotherapy, 8 received adjuvant chemoradiotherapy, and 1 received only chemoradiotherapy. The disease-free duration among these children ranges from 3 months to 160 months.

Although the etiological factors for the pulmonary RMS are unknown, it can be divided into two groups, those originating from normal lung and those from abnormal lung. Recently, there has been an increase in the number of cases detected with the availability of prenatal ultrasound scan. ${ }^{[24]}$

\begin{tabular}{|c|c|c|c|c|c|c|}
\hline Year & Reference & $\begin{array}{l}\text { Age } \\
\left(m^{*}\right)\end{array}$ & Sex & $\begin{array}{l}\text { Associated } \\
\text { cyst }\end{array}$ & Histology & Treatment \\
\hline 1971 & [7] & 72 & $\mathrm{~F}^{\prime}$ & No & Embryonal & $C T^{* *+R T^{\prime \prime}}$ \\
\hline 1977 & [2] & 18 & $\mathrm{M}^{*}$ & $\mathrm{CCAM}^{\mathrm{s}}$ & Embryonal & CT \\
\hline 1981 & [8] & 21 & M & No & Embryonal & CT \\
\hline 1981 & [9] & 30 & $\mathrm{~F}$ & $\mathrm{BC}^{\circledR}$ & Embryonal & CT \\
\hline 1982 & [10] & 156 & $\mathrm{~F}$ & No & Alveolar & $C T+R T$ \\
\hline \multirow[t]{3}{*}{1983} & [3] & 84 & $\mathrm{M}$ & No & Undifferentiated & $C T+R T$ \\
\hline & & 122 & M & No & Undifferentiated & $C T+R T$ \\
\hline & & 156 & $\mathrm{~F}$ & No & Embryonal & $C T+R T$ \\
\hline 1986 & [11] & 21 & $\mathrm{M}$ & CCAM & Embryonal & CT \\
\hline \multirow[t]{2}{*}{1987} & [12] & 21 & $\mathrm{~F}$ & Cyst & - & CT \\
\hline & & 30 & $\mathrm{~F}$ & Cyst & - & CT \\
\hline 1988 & [13] & 15 & $\mathrm{~F}$ & CCAM & - & - \\
\hline \multirow[t]{2}{*}{1989} & [14] & 22 & $\mathrm{~F}$ & Cyst & - & CT \\
\hline & & 18 & $\mathrm{~F}$ & Cyst & Embryonal & CT \\
\hline 1992 & [6] & 24 & $\mathrm{~F}$ & $B C$ & Embryonal & CT \\
\hline \multirow[t]{3}{*}{1993} & [15] & 96 & $\mathrm{~F}$ & CCAM & - & CT \\
\hline & & 36 & M & Cyst & Embryonal & CT \\
\hline & & 24 & $\mathrm{~F}$ & No & Embryonal & CT \\
\hline 1993 & [1] & 24 & - & No & - & CT \\
\hline 1993 & [16] & 18 & - & No & - & CT \\
\hline 1994 & [17] & 120 & $\mathrm{M}$ & No & Embryonal & ${ }^{\wedge} \mathrm{CT}+\mathrm{RT}$ \\
\hline 1995 & [18] & 22 & M & No & Alveolar & $C T+R T$ \\
\hline 1997 & [19] & 22 & $\mathrm{~F}$ & CCAM & Embryonal & CT \\
\hline 1998 & [5] & 168 & M & No & Undifferentiated & $C T+R T$ \\
\hline 2001 & [20] & 13 & $\mathrm{M}$ & CCAM & Embryonal & CT \\
\hline 2002 & [21] & 32 & $\mathrm{M}$ & No & Embryonal & $C T+R T$ \\
\hline 2005 & [22] & 24 & $\mathrm{~F}$ & CCAM & Pleomorphic & 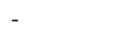 \\
\hline \multirow[t]{3}{*}{2011} & $\begin{array}{l}\text { Present } \\
\text { study }\end{array}$ & 36 & M & CCAM & Embryonal & CT \\
\hline & & 108 & $\mathrm{~F}$ & No & Embryonal & CT \\
\hline & & 36 & $\mathrm{~F}$ & No & Embryonal & . \\
\hline
\end{tabular}

${ }^{*} \mathrm{~m}$ - Months; ' $\mathrm{F}$ - Female; ${ }^{* *} \mathrm{CT}$ - Chemotherapy; ${ }^{\prime R T}$ - Radiotherapy; ${ }^{*} \mathrm{M}$ - Male; sCCAM - Congenital cystic adenomatoid malformation; ${ }^{\circledR B C}$ - Bronchogenic cyst; ${ }^{\wedge}$ Except this child, all underwent surgical excision

Two hypotheses were proposed for the origin of pulmonary RMS. First hypothesis states that tumor arises from heterotopic islets of striated muscles, thus explaining the frequent association of RMS with pulmonary malformations such as bronchogenic cysts, cystic adenomatosis and extralobar sequestration where these islets are usually present. In second hypothesis, a neoplastic transformation of the uncommitted mesenchymal cells present in the interstitial lung tissue or bronchiole. This seems to be more relevant for the cases not associated with cystic lesions. ${ }^{[25]}$

Surgical excision is considered the treatment of choice, adjuvant chemotherapy (vincristine, actinomycin, ifosfamide, and doxorubicin in combination) is recommended in all the cases and margin positive or residual disease should be irradiated. 
The presence of simultaneous cystic lesion could be considered one of the favourable prognostic factor because it helps in early detection and complete surgical removal.

To conclude, the tumors of the lung should be considered in the differential diagnosis of a child who presents with a cystic mass. The cystic pulmonary malformation can serve as a substrate for the development of primary RMS, identification of malformed pulmonary tissue requires a careful follow-up. The early surgical intervention may prevent the long-term morbidity and mortality associated with advanced disease. The role of surgery in all asymptomatic congenital pulmonary malformations requires further evaluation.

\section{ACKNOWLEDGMENT}

I would like to thank Dr. Padma M, Dr. Mamatha HS, Dr. Kavitha S from Department of Pediatric oncology, Dr. Geetashree Mukherjee from Department of Pathology and Dr. Rajeev L.K, Medical Oncologist at Kidwai Memorial Institute of Oncology, Bangalore for their help and support in preparing this manuscript.

\section{REFERENCES}

1. Hancock BJ, Di Lorenzo M, Youssef S, Yazbeck S, Marcotte JE, Collin PP. Childhood primary pulmonary neoplasms. J Pediatr Surg 1993;28:1133-6.

2. Ueda K, Gruppo R, Unger F, Martin L, Bove K. Rhabdomyosarcoma of lung arising in congenital cystic adenomatoid malformation. Cancer 1977;40:383-8.

3. Hartman GE, Shochat SJ. Primary pulmonary neoplasms of childhood: A review. Ann Thorac Surg 1983;36:108-19.

4. Maurer HM, Moon T, Donaldson M, Fernandez C, Gehan EA, Hammond D, et al. The intergroup rhabdomyosarcoma study: A preliminary report. Cancer 1977;40:2015-26.

5. Andrassy RJ, Wiener ES, Raney RB, Lawrence W, Lobe TE, Corpron CA, et al. Thoracic sarcomas in children. Ann Surg 1998;227:170-3.

6. McDonald S Jr, Heather JC. Neoplastic invasion of the pulmonary veins and left auricle. J Pathol Bacteriol 1939;48:533-43.

7. Fallon G, Schiller M, Kilman JW. Primary rhabdomyosarcoma of the bronchus. Ann Thorac Surg 1971;12:650-4.

8. Thomas WJ, Koenig HM, Ellwanger FR, Lightsey AL. Primary pulmonary rhabdomyosarcoma in childhood. Am J Dis Child 1981;135:469-71.

9. Crist WM, Raney RB Jr, Newton W, Lawrence W Jr, Tefft M, Foulkes MA. Intrathoracic soft tissue sarcomas in children. Cancer 1982;50:598-604.

10. Williams RA. Embryonal rhabdomyosarcoma occurring in cystic adenomatoid malformation. Pediatr Pathol 1986;5:118-9.

11. Allan BT, Day DL, Dehner LP. Primary pulmonary rhabdomyosarcoma of the lung in children. Report of two cases presenting with spontaneous pneumothorax. Cancer 1987;59:1005-11.

12. Shariff S, Thomas JA, Shetty N, D'Cunha S. Primary pulmonary rhabdomyosarcoma in a child, with a review of literature. J Surg Oncol 1988;38:261-4.

13. Hedlund GL, Bisset GS $3^{\text {rd }}$, Bove KE. Malignant neoplasms arising in cystic hamartomas of the lung in childhood. Radiology 1989;173:77-9.

14. Murphy JJ, Blair GK, Fraser GC, Ashmore PG, LeBlanc JG, Sett SS, et al. Rhabdomyosarcoma arising within congenital pulmonary cysts: Report of three cases. J Pediatr Surg 1992;27:1364-7.

15. McDermott VG, Mackenzie S, Hendry GM. Case report: Primary intrathoracic rhabdomyosarcoma: A rare childhood malignancy. Br J Radiol 1993;66:937-41.

16. Bogers AJ, Hazebroek FW, Molenaar J, Bos E. Surgical treatment of congenital bronchopulmonary disease in children. Eur J Cardiothorac Surg 1993;7:117-20.

17. Doval DC, Kannan V, Acharya R, Mukherjee G, Chandrashekhar M, Bapsy PP. Bronchial embryonal rhabdomyosarcoma: A case report. Acta Oncol 1994;33: 832-33.

18. Noda $T$, Todani $T$, Watanabe $\mathrm{Y}$, Uemura $\mathrm{S}$, Urushihara $\mathrm{N}$, Morotomi $Y$, et al. Alveolar rhabdomyosarcoma of the lung in a child. J Pediatr Surg 1995;30:1607-8.

19. d'Agostino S, Bonoldi E, Dante S, Meli S, Cappellari F, Musi L. Embryonal rhabdomyosarcoma of the lung arising in cystic adenomatoid malformation: Case report and review of the literature. J Pediatr Surg 1997;32:1381-3.

20. Ozcan C, Celik A, Ural Z, Veral A, Kandiloğlu G, Balik E. Primary pulmonary rhabdomyosarcoma arising within cystic adenomatoid malformation: A case report and review of the literature. J Pediatr Surg 2001;36:1062-5.

21. Iqbal $Y$, Abdullah MF, Al-Jadaan S, Trabichi H, Al Omari A Al-Sudairy R. Embryonal rhabdomyosarcoma of the lung in a child: Case report and literature review. Ann Saudi Med 2002;22:91-3.

22. Doladzas T, Arvelakis A, Karavokyros IG, Gougoudi E, Pikoulis $\mathrm{E}$, Patsouris $\mathrm{E}$, et al. Primary rhabdomyosarcoma of the lung arising over cystic pulmonary adenomatoid malformation. Pediatr Hematol Oncol 2005;22:525-9.

23. Revillon $Y$, Jan $D$, Plattner $V$, Sonigo $P$, Dommergues $M$, Mandelbrot L, et al. Congenital cystic adenomatoid malformation of the lung: Prenatal management and prognosis. J Pediatr Surg 1993;28:1009-11.

24. Aterman $\mathrm{K}$, Patel S. Striated muscle in the lung. Am J Anat 1970;128:341-58.

25. Krous HF, Sexauer CL. Embryonal rhabdomyosarcoma arising within a congenital bronchogenic cyst in a child. J Pediatr Surg $1981 ; 16: 506-8$.

How to cite this article: Lokesh KN, Premalata CS, Aruna Kumari BS, Appaji L. Primary pulmonary rhabdomyosarcoma in children: Report of three cases with review of literature. Indian J Med Paediatr Oncol 2013;34:38-41.

Source of Support: Nil, Conflict of Interest: None declared. 